\title{
The double helix and the 'wronged heroine'
}

\author{
Brenda Maddox
}

9 Pitt Street, London W8 4NX, UK (e-mail:bmaddox@pitt.demon.co.uk)

In 1962, James Watson, Francis Crick and Maurice Wilkins received the Nobel prize for the discovery of the structure of DNA. Notably absent from the podium was Rosalind Franklin, whose X-ray photographs of DNA contributed directly to the discovery of the double helix. Franklin's premature death, combined with misogynist treatment by the male scientific establishment, cast her as a feminist icon. This myth overshadowed her intellectual strength and independence both as a scientist and as an individual.

n late February 1953, Rosalind Franklin, a 33year-old physical chemist working in the biophysics unit of King's College in London, wrote in her notebooks that the structure of DNA had two chains. She had already worked out that the molecule had its phosphate groups on the outside and that DNA existed in two forms.

Two weeks later James Watson and Francis Crick, at the Cavendish Laboratory at Cambridge, built their now celebrated model of DNA as a double helix. They did it not only through brilliant intuition and a meeting of compatible minds, but also on the basis of Franklin's unpublished experimental evidence, which had reached them through irregular routes. She did not know that they had seen either her X-ray photograph (Fig. 1), showing unmistakable evidence of a helical structure, or her precise measurements of the unit cell (the smallest repeating unit) of the DNA crystal.

As Watson was to write candidly, "Rosy, of course, did not directly give us her data. For that matter, no one at King's realized they were in our hands." When this admission appeared in Watson's best-selling, much-acclaimed book of the discovery, The Double Helix, published in 1968 (ref. 1), he was a Harvard professor and Nobel laureate (he had shared the prize for medicine and physiology in 1962, with Crick and Maurice Wilkins of King's College.) By then Franklin had died - in 1958, at the age of 37, from ovarian cancer.

Other comments dismissive of "Rosy" in Watson's book caught the attention of the emerging women's movement in the late 1960s. "Clearly Rosy had to go or be put in her place [...] Unfortunately Maurice could not see any decent way to give Rosy the boot". And, "Certainly a bad way to go out into the foulness of a [...] November night was to be told by a woman to refrain from venturing an opinion about a subject for which you were not trained."

\section{A feminist icon}

Such flamboyantly chauvinist phrases were sufficient to launch the legend of Franklin, the wronged heroine. So too was Watson's insistence on judging Franklin by her appearance rather than by her performance as a scientist. (She was, when she came to King's from the French government laboratory where she had worked from 1947 to the end of 1950, a recognized expert on
"Science and everyday life cannot and should not be separated. Science, for me, gives a partial explanation of life. In so far as it goes, it is based on fact, experience and experiment." Rosalind Franklin, in a letter to her father, summer 1940.

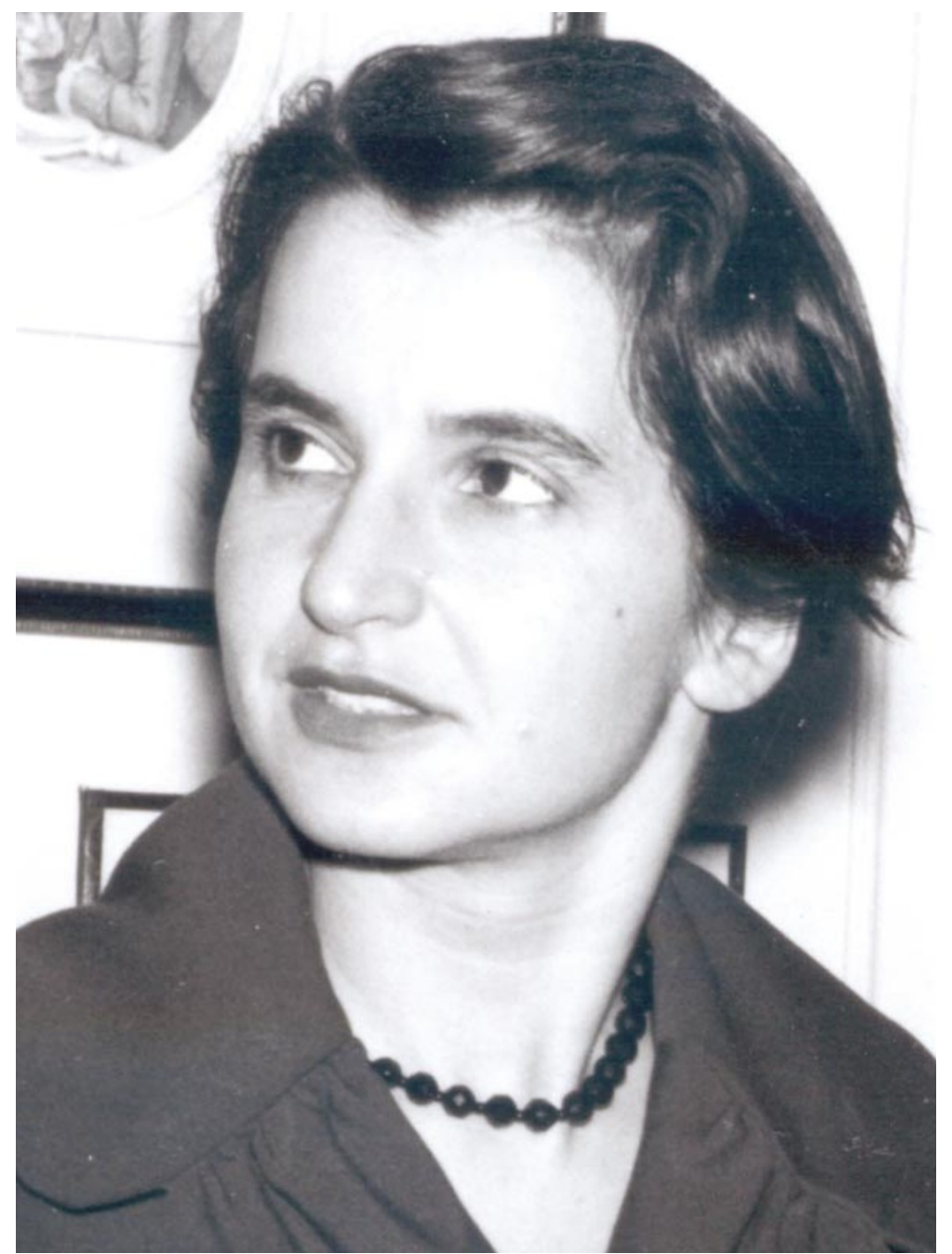

the structure of coals, carbons and disordered crystals, with many publications to her credit.)

The Franklin myth has continued to grow, abetted by the fact of her tragically early death. Franklin has become a feminist icon — the Sylvia Plath of molecular biology - seen as a genius whose gifts were sacrificed to the greater glory of the male. Her failure to win the Nobel prize has been given as a prime example 
Figure 1 "Her photographs are among the most beautiful $X$-ray photographs of any substance every taken." - J. D. Bernal, 1958. Franklin's X-ray diagram of the $B$ form of sodium thymonucleate (DNA) fibres, published in Nature on 25 April 1953, shows "in striking manner the features characteristic of helical structures" 5 . of the entrenched misogyny of the science establishment, rather than the consequence of the Nobel statute against posthumous awards.

Watson's caricature of the bad-tempered "Rosy" drew a counter-blast from her good friend, the American writer Anne Sayre, in Rosalind Franklin and DNA, published in 1975 (ref. 2). Sayre's book provided a much-needed corrective portrait, but was marred by a feminist bias. For example, it grossly underestimated the number of women scientists at King's in the early 1950s. Sayre maintained there was only one other than Franklin, whereas there were at least eight on the senior staff. She insisted, moreover, that women's exclusion from the King's senior common room deprived Franklin of the intellectual companionship of her colleagues. In fact, most of the scientific staff preferred to eat in the joint dining room, men and women together, and the women, in general, felt well treated at King's.

\section{Reassessing the facts}

As a biographer writing nearly three decades later and given access to Franklin's personal correspondence, I found a more attractive, capable woman than Watson had suggested, and a King's College more congenial and welcoming to women scientists than Sayre had allowed. I also found that Franklin felt singularly unhappy at King's, not so much because of her gender, but because of her class and religion: a wealthy Anglo-Jew felt out of place in a Church of England setting dominated by swirling cassocks and students studying for the priesthood. "At King's," she wrote to Sayre (albeit inaccurately), "there are neither Jews nor foreigners".

She was, in fact, so unhappy at King's that, in early 1953, getting out as fast as possible was far more important to her than finishing her work on DNA. How far she had advanced was reported in two articles in Nature $^{3,4}$ by Sir Aaron Klug, Franklin's closest collaborator at Birkbeck College, London, where she moved to from King's. He concluded that she had come very close to discovering the structure of DNA herself.

An irony of the story is that her own manuscript (coauthored by her student, R. G. Gosling and dated 17 March 1953) summarizing her results was already prepared by the time news reached King's that Watson and Crick had cracked the DNA secret. Thus she inserted a hand-written amendment to her manuscript - which was published in Nature on 25 April 1953 (ref. 5), along with the now-celebrated Watson and Crick paper and another by Wilkins, Herbert Wilson and Alec Stokes of King's - to say "Thus our general ideas are not inconsistent with the model proposed by Watson and Crick in the preceding communication". And so they should have been, for the Watson-Crick findings were based on her data.

There is no evidence that she knew that in late January 1953 Wilkins had innocently shown her Photograph 51, with its stark cross of black reflections (Fig. 1), to Watson, who was visiting King's. Nor did she know that in February 1953 Max Perutz, then at the Cavendish Laboratory, had let Watson and Crick see his copy of the Medical Research Council's report summarizing the work of all principal researchers, including Franklin's.

At the same time there is no evidence that Franklin felt bitter about their achievement or had any sense of having been outrun in a race that nobody but Watson and Crick knew was a race. Indeed, she could accept the Watson-Crick model as a hypothesis only. She wrote in Acta Crystallographica in September 1953 that "discrepancies prevent us from accepting it in detail".

\section{Belated credit}

Watson and Crick seem never to have told Franklin directly what they subsequently have said from public platforms long after her death - that they could not have discovered the double helix of DNA in the early months of 1953 without her work. This is all the more surprising in view of the close friendship that developed among the three of them - Watson, Crick and Franklin - during the remaining years of her life. During this time, shewas far happier at non-sectarian Birkbeck than she ever was at King's, and led a spirited team of researchers studying tobacco mosaic virus (TMV).

From 1954 until months before her death in April 1958, she, Watson and Crick corresponded, exchanged comments on each other's work on TMV, and had much friendly contact. At Wood's Hole, Massachusetts, in the summer of 1954 Watson offered Franklin a lift across the United States as he was driving to her destination, the California Institute of Technology. In the spring of 1956 she toured in Spain with Crick and his wife Odile and subsequently stayed with them in Cambridge when recuperating from her treatments for ovarian cancer. Characteristically, she was reticent about the nature of her illness. Crick told a friend who asked that he thought it was "something female".

In the years after leaving King's, Franklin published 17 papers, mainly on the structure of TMV (including four in Nature). She died proud of her world reputation in the research of coals, carbons and viruses. Given her determination to avoid fanciful speculation, she would never have imagined that she would be remembered as the unsung heroine of DNA. Nor could she have envisaged that King's College London, where she spent the unhappiest two years of her professional career, would dedicate a building — the Franklin-Wilkins building - in honour of her and the colleague with whom she had been barely on speaking terms.

doi:10.1038/nature01399

1. Watson, J. The Double Helix: A Personal Account of the Discovery of the Structure of DNA (Atheneum, New York, 1968).

2. Sayre, A. Rosalind Franklin and DNA (W. W. Norton \& Co., New York, 1975).

3. Klug, A. Rosalind Franklin and the discovery of the structure of DNA. Nature 219, 808-810, 843-844 (1968).

4. Klug, A. Rosalind Franklin and the double helix. Nature 248, 787-788 (1974).

5. Franklin, R. E. \& Gosling, R. G. Molecular configuration in sodium thymonucleate. Nature 171, 740-741 (1953).

6. Franklin, R. E. \& Gosling, R. G. The structure of sodium thymonucleate fibres: I. The influence of water content. II. The cylindrically symmetrical Patterson function. Acta Crystallogr. 6, 673-677, 678-685 (1953). 